\title{
Soil Properties under Various Stages of Secondary Forests at Sarawak, East Malaysia
}

\author{
K. Karyati ${ }^{1 *}$, I.B. Ipor ${ }^{2}$, I. Jusoh ${ }^{2}$ and M.E. Wasli ${ }^{2}$ \\ ${ }^{1}$ Faculty of Forestry, University of Mulawarman, Samarinda, East Kalimantan, Indonesia \\ ${ }^{2}$ Faculty of Resource Science and Technology, Universiti Malaysia Sarawak, \\ Kota Samarahan, Sarawak, Malaysia
}

Date Received: 07-11-2013 Date Accepted: 26-01-2014

\begin{abstract}
Changes in the forest community during secondary succession are influencing in various soil properties. However, there is limited information available on the soil properties under different stages of secondary forests in Sarawak. The aims of this study are to clarify the soil morphological and physicochemical properties at secondary forests under different age stands after similar land change (slash and burn). Field surveys were conducted at 3, 5, 10, and 20 years old of secondary forests in Sabal, Sarawak. Different fallow time influence changing soil properties in various stage secondary forests. A number of soil properties affected soil development process and land use change. Soil morphological and physicochemical properties differed under different stages of fallow periods. The results showed that the soils under different stages of fallow lands after shifting cultivation in the study sites was categorized in acidic soil as indicated by $\mathrm{pH}\left(\mathrm{H}_{2} \mathrm{O}\right)$ values of below than 5 and the low content of T-C and T-N as well as exchangeable bases. The close relationship can be assumed between soil development process and vegetation succession. The knowledge of forest soil properties is essential to understand the change and development process under various stages secondary forests. The comprehensive understanding about soil properties and development process is important in order to conserve and manage secondary forests.
\end{abstract}

Keywords: secondary forest, fallow age, shifting cultivation, soil morphological properties, soil physicochemical properties

\section{Introduction}

Shifting cultivation has been practiced all over the world and two-thirds of the world's secondary forest in 1980 was shifting cultivation fallow (Lanly, 1982). Historically, shifting cultivation has created much impact on the general landscape of rural Malaysia particularly in Sabah and Sarawak over the last 100 years (Latiff \& Zakri, 1998). In addition, about $49 \%$ of the area deforested annually in tropical Asia is attributed to shifting cultivation (Lanly, 1982). Shifting cultivation is accounted for some $28 \%$ of land use and it has been suggested that some 3.2 million ha in Sarawak are subject to shifting cultivation (Jomo et al., 2004).

\footnotetext{
*Correspondence: karyati.hanapi@yahoo.com Tel:+62 541749068

ISSN 2235-9370 Print/ISSN 2235-9362 Online (C University of Sri Jayewardenepura
} 
Secondary forest is the type of vegetation that results after the natural high forest vegetation has been disturbed or cleared for shifting cultivation prior to abandonment (Misra, 1992; Abebrese, 2002; Johnson \& Miyanishi, 2007; Keddy, 2007). After field abandonment, the secondary forest develops naturally (Van Do et al., 2010). The secondary forests are reflected in their structure and extent of vegetative cover, as well as their composition in terms of dominant and secondary species (Mittelman, 2001).

Forest succession alters the chemical, physical, and biological properties of the soil through their occupancy of the area, and it is likely that these alterations contribute to the relative changes in the abundance of the dominant plant species that characterises successional aspect on the land (Fisher \& Binkley, 2000). Rapid changes in the secondary successional fallow environment is reflected by the declining in light availability for the growth of the shoot system as well as the changes in the nutrient distribution within the soil horizon during the early to late successional fallow environment (Ramakrishnan \& Kushwaha, 2001). A number of soil properties can be used to infer a great deal about how a particular soil influences plant growth and its well-being (Harris, 1992; Fisher \& Binkley, 2000). It is the ability of the soil to supply nutrient elements in the amounts, forms, and proportions required for maximum plant growth. The plant growth depends on the physicochemical properties and organic matter content of the soil (Hazra \& Som, 2006).

The soil properties at fallow lands under shifting cultivation could be characterised by strongly acidic nature with low levels of exchangeable bases (Nakano \& Miyauchi, 1996; Etsuko et al., 2004; Wasli et al., 2009). Schedlbauer and Kavanagh (2008) noted that mineral soil C storage beneath secondary forests was relatively consistent as secondary forest development progressed. However, Feldpausch et al. (2007) reported that the level of C content and all nutrient concentrations in soil had a decreasing trend with increasing soil depth in the secondary forests after abandonment. In addition, Lu et al. (2002) reported that

soil nutrients such as $\mathrm{Ca}, \mathrm{Mg}, \mathrm{K}$, and $\mathrm{N}$ decrease with the depth in the soil studied in secondary succession forest. Andriesse \& Schelhaas (1987a) showed a noticeable increase in cation exchange capacity (CEC) of the topsoil with burning in their experimental site in Sarawak with no dry season. They reported that this rise in CEC was closely related to the increase in $\mathrm{C}$ because of the incomplete burning of wet organic matter.

Several studies on soil properties under tropical secondary forests in Sarawak, Malaysia (Andriesse \& Schelhaas, 1987a, 1987b; Tanaka et al., 2007a, 2007b; Tanaka et al., 2009; Wasli et al., 2009) have been reported. However, still limited studies focused on soil properties at early succession stage of secondary forests after abandonment. In this study, the soil morphological and physicochemical properties in tropical secondary forests, especially at different stages of fallow lands were conducted.

\section{Materials and Methods}

\subsection{Study Sites}

For clarification on the soil properties (morphological and physicochemical properties) under various stage of secondary forests, the assessment was conducted in the secondary forests with the age of 3 years, 5 years, 10 years, and 20 years (hereafter called Temuda I, Temuda II, Belukar I, and Belukar II, respectively) in Sabal, Sri Aman, Sarawak, East Malaysia (Fig. 1) where the previous study on vegetation composition and diversity was conducted by Karyati et al. (2013). The original vegetation at Sabal site is lowland mixed dipterocarp forest with heath forest (Kerangas) (Whitmore, 1975; Kendawang et al., 2007). The soils of the study site are derived from non-calcareous sedimentary rocks 
consisting of fine and whitish sandstone during the mid Tertiary period (Butt, 1983). Most of the soils are classified into Oxyaquic or Spodic Quartzipsamments at Sabal site based on the USDA classification system (Soil Survey Staff, 1994). Climate data are collected from Sri Aman Station, which is located nearest to the study sites with consistent climatic records. During the last 20 years (1992-2011), the study sites receive average annual 3,491 mm year ${ }^{-1}$ of rainfall, $26.6^{\circ} \mathrm{C}$ of monthly temperature, and $85.1 \%$ of relative humidity. The climate is classified into type A on the Schmidt-Ferguson classification system (1951). Sabal region is characterized as zone A with Q (Quotient) of 0.013 where very humid area with vegetation of tropical rain forest (Karyati et al., 2012).

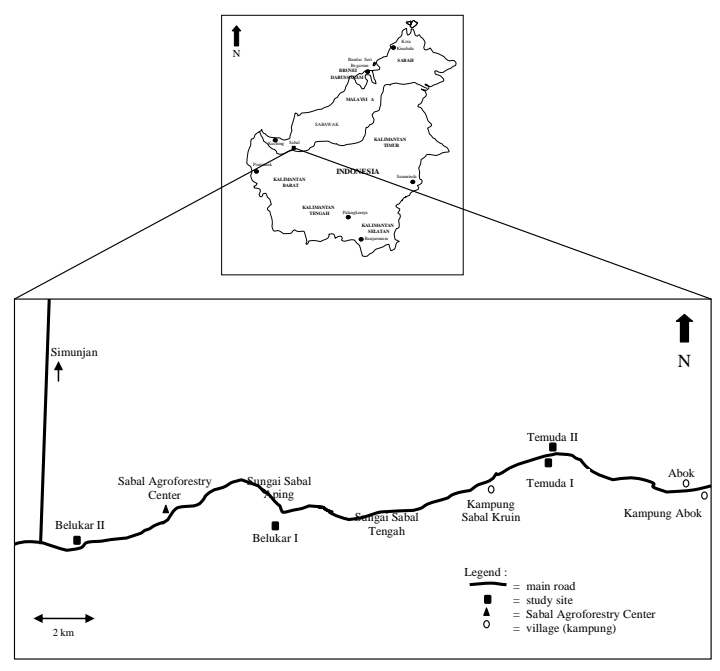

Fig. 1: Map of the study sites.

\subsection{Soil Profile Description}

For soil profile description, a soil pit with the depth of 1 meter was dug at the centre of each study site, such as Temuda I, Temuda II, Belukar I, and Belukar II, respectively. Soil profile descriptions were conducted adopting the standard procedures by International Soil Science Society (ISSS) (NRCS, 2002). The soil profile description was conducted by observing the characteristics of the soils moving towards the bottom of profile. Some of the characteristics were distinguished such as depth, boundary, colour, field texture, structure, roots, and hardness. Soil colour was determined by referring to Munsell soil colour chart, while soil texture in the field was determined by "feel" method. Soil hardness was measured at every horizon using the Yamanaka-type penetrometer.

\subsection{Soil Sampling and Physicochemical Analyses}

At each study site, the soils on nine quadrates of $20 \mathrm{~m} \times 20 \mathrm{~m}$ were analyzed. Soil samples were collected at the depths of $0-10 \mathrm{~cm}$ (surface soil) and 20-30 cm (sub-soils) from three random points within the quadrate. The soil samples obtained in triplicate were mixed well to yield one composite sample. The samples were air-dried and then sieved through $2 \mathrm{~mm}$ mesh for physicochemical analysis. Undisturbed soil samples were also collected using $100 \mathrm{~cm}^{3}$ core sampler for determination of soil physical properties.

Soil $\mathrm{pH}$ was determined in distilled water and $1 \mathrm{M} \mathrm{KCl}$ in a soil to solution ratio of 1:5 by the glass electrode method. Electrical conductivity (EC) was measured using a 
conductivity meter (Eutech Instruments-Cyberscan CON 11). The solution was standardized using conductivity meter and was calibrated by standard potassium chloride solution. The content of total carbon (T-C) and nitrogen (T-N) were analyzed using CHN analyzer (FlashEA 1112 Series). Soil CEC was analyzed by distillation (based on MS678 Part V: 1980). Soil exchangeable cations of calcium, magnesium, potassium, and natrium (Exch-Ca, Exch-Mg, Exch-K, and Exch-Na) were analyzed by leaching with neutral ammonium acetate using ICP-AES (based on MS678 Part IV: 1980). Particle size distribution was determined using mechanical analysis and hydrometer. The analysis of soil $\mathrm{pH}\left(\mathrm{H}_{2} \mathrm{O}\right), \mathrm{pH}(\mathrm{KCl}), \mathrm{EC}, \mathrm{TC}$, TN, bulk density, and porosity were conducted at Laboratory of Soil Chemistry, Faculty of Resource Science and Technology, Universiti Malaysia Sarawak (Unimas). The analysis of CEC, soil exchangeable cations (Exch-Ca, Exch-Mg, Exch-K, and Exch-Na), and particle size distribution were conducted at Agriculture Research Centre (ARC) Sarawak, Malaysia Agricultural Department.

To compare soil properties among four different stages of secondary forests at the depths of $0-10 \mathrm{~cm}$ and $20-30 \mathrm{~cm}$, one-way analysis of variance (ANOVA) by Tukey's tests was used. The statistical tests were conducted using SPSS version 18 for Windows (SPSS Inc., 2012).

\section{Results and Discussion}

\subsection{Soil morphological properties under various stages of secondary forests}

Information on the soil morphological properties on a given land can be determined by observing the profile development at various depths of the soil. Table 1 presents a summary of soil profile description in the study sites. Under similar land use history (slash and burn after shifting cultivation), there were some clear differences among four study sites although soils corresponded to the same soil order, namely Ultisols (Soil Survey Staff, 2006). Soil profiles of Belukar II showed different content of parent materials as compared to the other three sites. Soil of Temuda I, Temuda II, and Belukar I consisted of non-calcareous sedimentary rocks, while the soil of Belukar II was mainly shale and predominantly sedimentary rocks. Such properties lead to differences in terms of soil classification under Sarawak Soil Classification system for the study sites. The soils of Temuda I, Temuda II, and Belukar I were classified into Grey-White Podzolic soils, while Red Yellow Podzolic soils observed in Belukar II (Teng, 1993). Both soil types consist of parent materials of mainly old alluvium, colluvium or residuum derived from arenaceous sedimentary rocks.

According to the "feel" texture method the soils at Temuda I were classified into sandy loam at horizon $\mathrm{O}$ and sandy clay loam at the other horizons (Table 1). In this site, the soil structure had moderate very fine sub-angular block to moderate fine sub-angular block with 17 to $19 \mathrm{~mm}$ in soil hardness. In horizons of Temuda II, the soil textures were classified into loamy sand, sandy clay, and sandy clay loam. The soil structure was moderate fine subangular block at all horizons, except moderate very fine to fine sub-angular block at horizon AE. The soil hardness was 17 to $21 \mathrm{~mm}$. The result of observation in Belukar I, the soil texture were loamy sand at horizons $1 \mathrm{~A}, 1 \mathrm{E}$ and $2 \mathrm{E} 2$, sandy loam to loamy sand at horizon $2 \mathrm{~A}$ and loamy sand to sand at horizon $2 \mathrm{E} 1$. The observed soil structure were weak very fine subangular blocky at horizons $1 \mathrm{~A}$ and $1 \mathrm{E}$ moderate vey fine sub-angular blocky at horizon $2 \mathrm{~A}$ and weak to moderate very fine sub-angular blocky at horizons 2E1 and 2E2. The soils of this site had 13 to $22 \mathrm{~mm}$ in hardness. In Belukar II, the soils were classified into silty clay loam 
and silt clay at horizon A and B1, while at horizons B2 and BC were clay based on the "feel" texture method. The soil structures were weak fine sub-angular blocky, moderate fine subangular blocky, strong medium to coarse sub-angular blocky, and massive at horizons A, B1, $\mathrm{B} 2$, and $\mathrm{BC}$, respectively. The soil hardness was 12 to $21 \mathrm{~mm}$.

Table 1: Summary of soil profile description in the study sites.

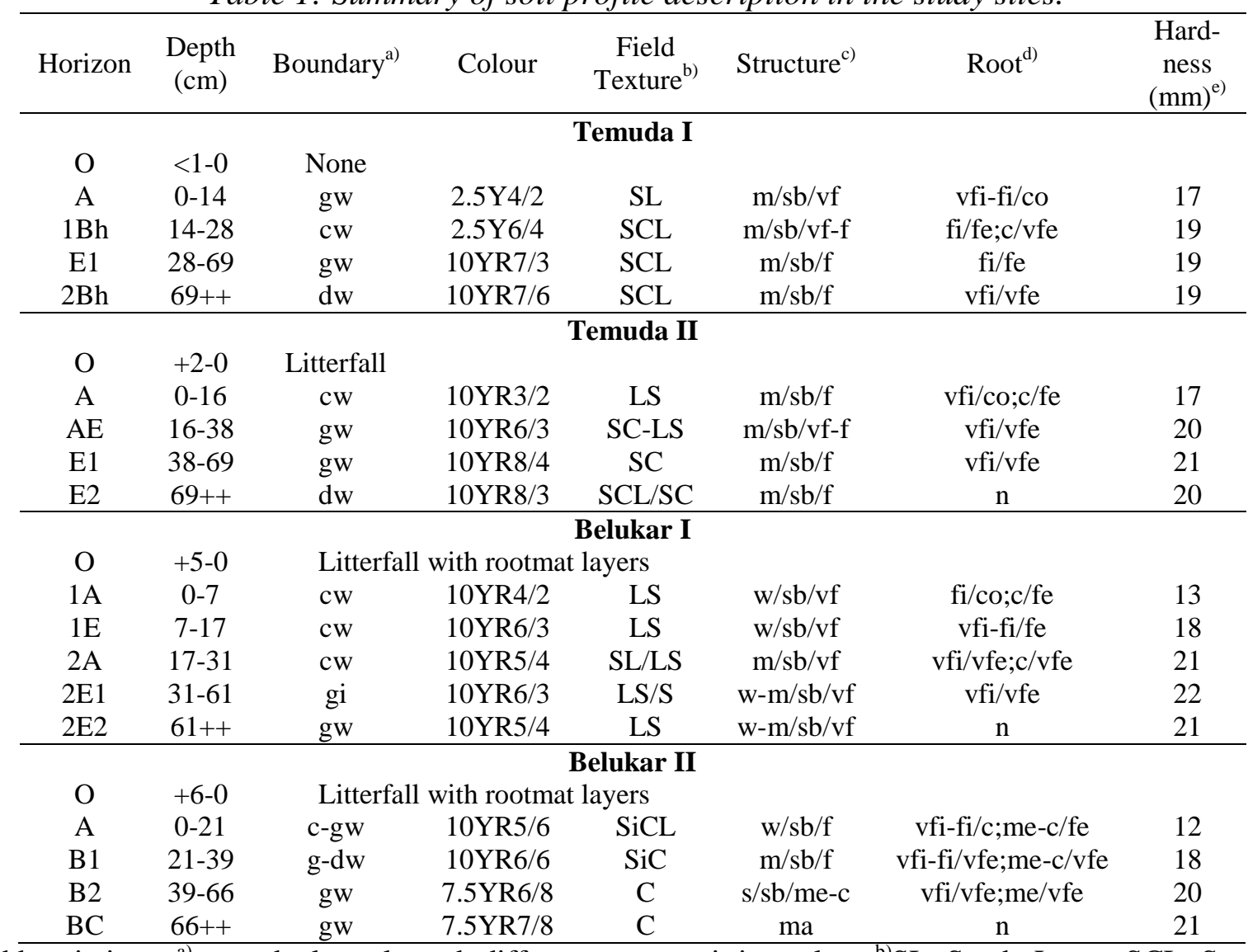

Abbreviations: ${ }^{a)} \mathrm{g}=$ gradual, $\mathrm{c}=$ clear, $\mathrm{d}=$ diffuse, $\mathrm{w}=$ wavy, $\mathrm{i}=$ irregular $;{ }^{\mathrm{b})} \mathrm{SL}=$ Sandy Loam, $\mathrm{SCL}=$ Sandy Clay Loam, LS=Loamy Sand, SC=Sandy Clay, S=Sand, SiCL=Silty Clay Loam, SiC=Silt Clay, $\mathrm{C}=\mathrm{Clay} ;{ }^{\mathrm{c})} \mathrm{w}=$ weak, $\mathrm{m}=$ moderate, $\mathrm{s}=\mathrm{strong}, \mathrm{sb}=$ sub-angular blocky, ma=massive, $\mathrm{vf}=\mathrm{very}$ fine, $\mathrm{f}=$ fine, me=medium, $c=$ coarse; ${ }^{d}$ vfi=very fine; fi=fine; me=medium; $c=$ coarse; $n=$ none; vfe=very few; $\mathrm{fe}=\mathrm{few} ; \mathrm{co}=\mathrm{common} ;{ }^{\mathrm{e}} \mathrm{Hardness}$ was measured using a Yamanaka-type penetrometer.

Differences in soil morphological properties under secondary forests could be observed under different stages of fallow period. The soil texture showed the differences among the soil profiles in the study sites in terms of "feel" method observation. These differences were also distinctive when the colour for each horizon between the soils profiles was compared. The differences in soil colour for each soil profile indicate the amount of organic matter in the soil, which is generally well correlated with the soil fertility and decomposition level (Fisher \& Binkley, 2000). Relative differences on the soil structure and root as well as the soil hardness were observed in each soil profile. Some differences may probably be due to shifting cultivation activity before abandoning the lands. A number of soil morphological attributes may affect soil development process under the succession process: soil texture (size distribution of particles), structure (arrangement of soil particles), depth of each soil horizons, penetration of roots from above vegetation and soil hardness with increasing soil depth as well as accumulation of litter fall at surface soils. The accumulation 
of litter fall at surface soils will lead to large amount of organic matter pool at the surface soil horizon. Organic matter that normally accumulates under forest provides an environment for higher microbial activities (Simmonds, 1972; Oriola et al., 2010). Moreover, the organic matter is highly influenced by the plant cover as this generates the litter that constitutes its major raw material. As for the case in this study, the increase of $\mathrm{O}$ horizon layer with increasing fallow period will lead to the increase in the organic matter content at forest floor surface which can be attributed to the larger foliage cover of forest helps to reduce the impact of soil erosion in removing surface organic matter (Oriola et al., 2010). During early stage secondary succession of fallow lands after shifting cultivation, the floristic composition was dominated and obtained by many similar species in Temuda I, Temuda II, and Belukar I. However, Belukar II showed relatively different species composition among all study sites. This showed that species composition at abandoned lands after burning begin to change after 20 years of abandonment (Karyati et al., 2013). The above vegetation is important source to organic matter accumulation. The differences of vegetation composition may lead to differences in organic matter accumulation at different fallow ages in four study sites.

\subsection{Soil physicochemical properties under various stages of secondary forests}

The soil physicochemical properties at different ages of secondary forests are summarized in Table 2 . In general, the soils of all study sites were strongly acidic with $\mathrm{pH}$ $\left(\mathrm{H}_{2} \mathrm{O}\right)$ values of less than 5 and the low content of T-C and T-N as well as exchangeable bases. This was probably due to the ash effect after burning where accumulation and addition process of nutrient during fallow period derived from the amount of biomass supplied during burning. This was also probably influenced by process of nutrient uptake by vegetation as well as leaching and decomposition process during early succession process. Similar pattern in soil pH changes after burning was also reported by Etsuko et al. (2004) on tropical soils after slash and burn cultivation at Northern Laos. During the fallow period, the loss of exchangeable bases from the soils and concomitant soil acidification occur because of leaching and uptake by recovering secondary vegetation (Uhl, 1987; Tanaka et al., 2007b). The soils at the early stages of secondary forest tended to be less acidic with higher contents of exchangeable $\mathrm{Ca}$ and $\mathrm{Mg}$. This could be ascribed to the remaining effects of ash (Juo \& Manu, 1996; Wasli et al., 2009), suggesting that a small ash input under intensified shifting cultivation with a shorter fallow period could still improve soil fertility to some extent (Tanaka et al., 2009).

The values of T-C and T-N decreased at the depth of $0-10 \mathrm{~cm}$ to $20-30 \mathrm{~cm}$ at different stages of secondary forests. The similar trend was also reported by Feldpausch et al. (2007). The relationships between $\mathrm{T}-\mathrm{N}$ and $\mathrm{C} / \mathrm{N}$ ratio at the depth of $0-10 \mathrm{~cm}$ in the study sites were displayed by a linear model as illustrated in Fig. 2. The content of the soil T-N might be influenced by accumulation process of soil organic matter during, both inputs process from litterfall and output process by decomposition (biological fixation) during the early stages of fallow periods. Especially in Belukar II whereby the level of $\mathrm{C} / \mathrm{N}$ ratio at subsoils $(20-30 \mathrm{~cm}$ depth) is tended to be higher as compare to other sites, such finding shows that both the quality of soil organic matter and the actual amount of mineral $\mathrm{N}$ is substantial as compared to land with younger fallow age. The levels of T-C and CEC at 0-10 cm depth showed no significant differences in all study sites, except for soils in Belukar II at 0-10 cm depth. At this site, the levels of T-C, T-N, and CEC were the highest.

The contents of exchangeable $\mathrm{Ca}, \mathrm{Mg}$, and $\mathrm{K}$ were higher at the depth of $0-10 \mathrm{~cm}$ than at the depth of $20-30 \mathrm{~cm}$. The exchangeable $\mathrm{Ca}$ and $\mathrm{Mg}$ showed no significant difference between Temuda I and Temuda II as well as Belukar II, but Temuda I and Temuda II were 
significantly different compared to Belukar I and Belukar II at the depth of $0-10 \mathrm{~cm}$. At the same time, exchangeable $\mathrm{Na}$ of all study sites at $0-10 \mathrm{~cm}$ depth showed no significant differences, except in Belukar II. The higher amount of Ca corresponds to the higher $\mathrm{pH}$ value (Etsuko et al., 2004). This trend was similar with the study in secondary forest of Amazonian by Lu et al. (2002), but contrast with the study of Ohta et al. (1993). The contents of exchangeable $\mathrm{K}$ were minimum and maximum at the depth of $10-20 \mathrm{~cm}$ (E horizon) and 30$80 \mathrm{~cm}$ (upper B horizon) at lowland Dipterocarp forest in East Kalimantan, Indonesia (Ohta et al., 1993). The higher contents of exchangeable $\mathrm{Ca}$ and $\mathrm{Mg}$ in the topsoils were due to their biological accumulation through litter supply and their lower mobility in soil (Ohta et al., 1993).

Table 2: Physicochemical properties of the soils in the study sites.

\begin{tabular}{|c|c|c|c|c|}
\hline \multirow{2}{*}{ Parameter } & \multicolumn{4}{|c|}{$0-10 \mathrm{~cm}(\mathrm{n}=9)$} \\
\hline & Temuda I & Temuda II & Belukar I & Belukar II \\
\hline $\mathrm{pH}\left(\mathrm{H}_{2} \mathrm{O}\right)$ & $4.71(0.13)^{\mathrm{ab}}$ & $4.50(0.26)^{\mathrm{a}}$ & $4.88(0.16)^{b}$ & $4.85(0.14)^{b}$ \\
\hline $\mathrm{pH}(\mathrm{KCl})$ & $3.72(0.24)^{b}$ & $3.59(0.15)^{\mathrm{ab}}$ & $3.43(0.28)^{\mathrm{a}}$ & $3.52(0.09)^{\mathrm{ab}}$ \\
\hline $\mathrm{EC}$ & $7.55(2.05)^{\mathrm{a}}$ & $9.18(1.05)^{\mathrm{a}}$ & $8.41(1.50)^{\mathrm{a}}$ & $9.02(1.79)^{\mathrm{a}}$ \\
\hline $\mathrm{T}-\mathrm{C}$ & $8.0(0.1)^{\mathrm{a}}$ & $8.0(0.5)^{\mathrm{a}}$ & $7.9(0.4)^{\mathrm{a}}$ & $8.5(0.4)^{b}$ \\
\hline $\mathrm{T}-\mathrm{N}$ & $0.52(0.01)^{\mathrm{ab}}$ & $0.53(0.08)^{a b}$ & $0.48(0.05)^{\mathrm{a}}$ & $0.57(0.04)^{b}$ \\
\hline $\mathrm{C} / \mathrm{N}$ ratio & $15.4(0.2)^{\mathrm{ab}}$ & $15.3(1.68)^{\mathrm{ab}}$ & $16.7(1.8)^{\mathrm{b}}$ & $14.8(1.2)^{\mathrm{a}}$ \\
\hline CEC & $12.6(3.50)^{\mathrm{a}}$ & $20.6(6.8)^{\mathrm{a}}$ & $16.9(6.6)^{\mathrm{a}}$ & $39.1(11.3)^{b}$ \\
\hline Exch-Ca & $0.04(0.02)^{\mathrm{a}}$ & $0.13(0.04)^{\mathrm{a}}$ & $0.53(0.26)^{b}$ & $0.41(0.17)^{\mathrm{b}}$ \\
\hline Exch-Mg & $0.05(0.03)^{\mathrm{a}}$ & $0.08(0.05)^{\mathrm{a}}$ & $0.21(0.11)^{b}$ & $0.17(0.06)^{b}$ \\
\hline Exch-K & $0.05(0.03)^{\mathrm{a}}$ & $0.07(0.04)^{\mathrm{a}}$ & $0.08(0.05)^{\mathrm{ab}}$ & $0.12(0.02)^{b}$ \\
\hline Exch-Na & $0.02(0.01)^{\mathrm{a}}$ & $0.02(0.01)^{\mathrm{a}}$ & $0.03(0.02)^{\mathrm{a}}$ & $1.58(0.33)^{b}$ \\
\hline Clay & $15.7(4.6)^{\mathrm{a}}$ & $13.9(3.1)^{\mathrm{a}}$ & $15.9(7.6)^{\mathrm{a}}$ & $30.2(4.0)^{\mathrm{b}}$ \\
\hline Silt & $11.6(5.4)^{\mathrm{b}}$ & $7.6(1.9)^{\mathrm{ab}}$ & $4.7(2.8)^{\mathrm{a}}$ & $19.3(4.9)^{\mathrm{c}}$ \\
\hline Sand & $72.7(9.1)^{\mathrm{b}}$ & $78.4(4.6)^{b}$ & $79.4(9.6)^{b}$ & $50.5(7.5)^{\mathrm{a}}$ \\
\hline Bulk density & $1.09(0.16)^{b c}$ & $1.11(0.08)^{\mathrm{c}}$ & $0.94(0.16)^{\mathrm{ab}}$ & $0.86(0.09)^{\mathrm{a}}$ \\
\hline Porosity & $0.59(0.06)^{\mathrm{ab}}$ & $0.58(0.03)^{\mathrm{a}}$ & $0.65(0.06)^{\mathrm{bc}}$ & $0.68(0.03)^{\mathrm{c}}$ \\
\hline \multirow{2}{*}{ Parameter } & \multicolumn{4}{|c|}{$20-30 \mathrm{~cm}(\mathrm{n}=9)$} \\
\hline & Temuda I & Temuda II & Belukar I & Belukar II \\
\hline $\mathrm{pH}\left(\mathrm{H}_{2} \mathrm{O}\right)$ & $4.81(0.09)^{\mathrm{ab}}$ & $4.63(0.20)^{\mathrm{a}}$ & $4.89(0.14)^{b}$ & $4.87(0.15)^{b}$ \\
\hline $\mathrm{pH}(\mathrm{KCl})$ & $3.73(0.16)^{\mathrm{a}}$ & $3.81(0.14)^{\mathrm{a}}$ & $3.89(0.10)^{\mathrm{a}}$ & $3.74(0.16)^{\mathrm{a}}$ \\
\hline $\mathrm{EC}$ & $6.50(1.46)^{\mathrm{a}}$ & $6.26(2.11)^{\mathrm{a}}$ & $4.92(1.20)^{\mathrm{a}}$ & $7.36(2.59)^{\mathrm{a}}$ \\
\hline $\mathrm{T}-\mathrm{C}$ & $6.9(0.1)^{\mathrm{a}}$ & $7.1(0.3)^{\mathrm{a}}$ & $7.43(0.88)^{\mathrm{a}}$ & $7.3(0.2)^{\mathrm{a}}$ \\
\hline $\mathrm{T}-\mathrm{N}$ & $0.51(0.06)^{\mathrm{a}}$ & $0.50(0.08)^{\mathrm{a}}$ & $0.53(0.11)^{\mathrm{a}}$ & $0.48(0.03)^{\mathrm{a}}$ \\
\hline $\mathrm{C} / \mathrm{N}$ ratio & $13.7(1.5)^{\mathrm{a}}$ & $14.5(2.3)^{\mathrm{a}}$ & $14.4(2.7)^{\mathrm{a}}$ & $15.1(0.9)^{\mathrm{a}}$ \\
\hline CEC & $14.9(8.0)^{\mathrm{a}}$ & $16.1(6.4)^{\mathrm{a}}$ & $12.1(4.7)^{\mathrm{a}}$ & $18.6(6.3)^{\mathrm{a}}$ \\
\hline Exch-Ca & $0.08(0.05)^{\mathrm{ab}}$ & $0.03(0.02)^{\mathrm{a}}$ & $0.22(0.17)^{b}$ & $0.23(0.18)^{b}$ \\
\hline Exch-Mg & $0.02(0.02)^{\mathrm{a}}$ & $0.02(0.02)^{\mathrm{a}}$ & $0.05(0.04)^{\mathrm{a}}$ & $0.05(0.03)^{\mathrm{a}}$ \\
\hline Exch-K & $0.02(0.02)^{\mathrm{a}}$ & $0.01(0.01)^{\mathrm{a}}$ & $0.05(0.03)^{b}$ & $0.06(0.02)^{b}$ \\
\hline Exch-Na & $0.02(0.02)^{\mathrm{a}}$ & $0.02(0.02)^{\mathrm{a}}$ & $1.20(0.26)^{\mathrm{b}}$ & $0.05(0.02)^{\mathrm{a}}$ \\
\hline Clay & $18.2(4.6)^{b}$ & $22.0(7.4)^{\mathrm{b}}$ & $8.3(3.2)^{\mathrm{a}}$ & $45.2(9.0)^{\mathrm{c}}$ \\
\hline Silt & $8.8(4.8)^{\mathrm{ab}}$ & $13.1(3.7)^{b c}$ & $4.1(2.8)^{\mathrm{a}}$ & $16.6(4.9)^{\mathrm{c}}$ \\
\hline Sand & $73.0(9.1)^{\mathrm{b}}$ & $64.9(9.9)^{\mathrm{b}}$ & $87.6(5.3)^{\mathrm{c}}$ & $38.2(4.6)^{\mathrm{a}}$ \\
\hline Bulk density & $1.45(0.12)^{\mathrm{ab}}$ & $1.36(0.16)^{\mathrm{ab}}$ & $1.52(0.14)^{b}$ & $1.31(0.12)^{\mathrm{a}}$ \\
\hline Porosity & $0.45(0.04)^{\mathrm{ab}}$ & $0.48(0.06)^{\mathrm{ab}}$ & $0.42(0.05)^{\mathrm{a}}$ & $0.50(0.05)^{b}$ \\
\hline
\end{tabular}

$\mathrm{EC}=$ electrical conductivity $(\mu \mathrm{S}) ; \mathrm{T}-\mathrm{C}=$ total carbon and $\mathrm{T}-\mathrm{N}=$ total nitrogen $(\%)$; $\mathrm{CEC}=$ cation exchange capacity, Exch-Ca, Exch-Mg, Exch-K, and Exch-Na = exchangeable calcium, exchangeable magnesium, exchangeable potassium, and exchangeable natrium $\left(\mathrm{cmol}_{\mathrm{c}} \mathrm{kg}^{-1}\right)$; clay, silt, sand, and porosity in percentage $(\%)$; bulk density in $\left(\mathrm{g} \mathrm{mL}^{-1}\right)$. Values are average and standard deviation (SD) in parentheses. Different letters in each line indicate a significant difference at 5\% level by Tukey's test among different ages of secondary forests. 


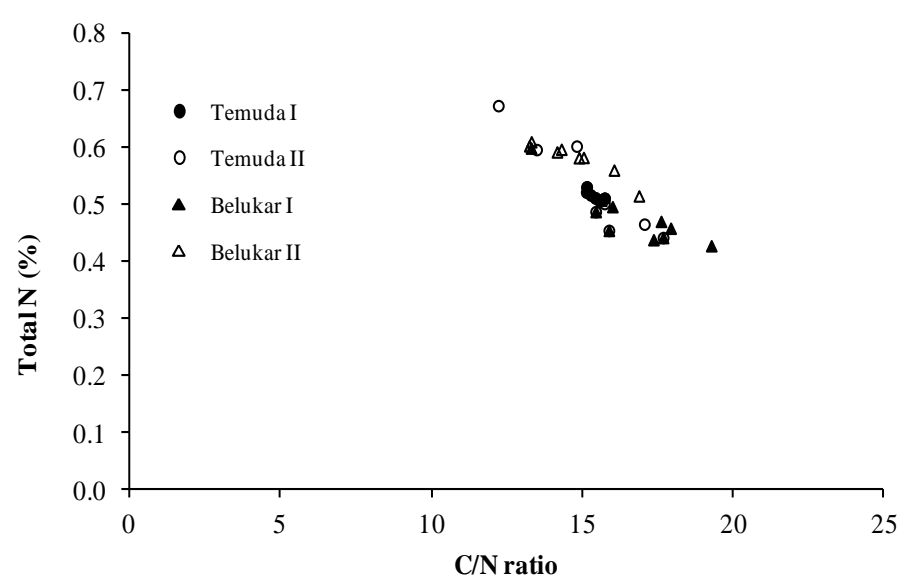

Fig. 2: Relationship between total $N$ and $C / N$ ratio at the depth of $0-10 \mathrm{~cm}$ in the study sites. Temuda I $\left(y=-0.03 x+0.98, R^{2}=0.68\right)$, Temuda II $\left(y=-0.04 x+1.20, R^{2}=0.86\right)$, Belukar I $(y=-$ $\left.0.03 x+0.91, R^{2}=0.77\right)$, and Belukar II $\left(y=-0.03 x+0.96, R^{2}=0.74\right)$.

Table 2 showed that exchangeable $\mathrm{Ca}, \mathrm{Mg}, \mathrm{K}$, and sum of exchangeable bases tended to increase with an increased in fallow age. Accumulation of soil organic matter during the fallow period and ash deposits from the burned biomass are the main factors contributing to increased soil fertility at the end of the fallow period. The biomass of the fallow vegetation is generally a major pool for potassium, calcium and magnesium (Nye \& Greenland, 1960; Jordan, 1985: Andriesse \& Scbelbaas, 1987b; Sanchez, 1987). In contrast, soil concentration of exchangeable $\mathrm{Ca}$ decreased with increasing stand age in primary and secondary forests in Eastern Amazônia, while soil concentration of exchangeable $\mathrm{Mg}$ were higher in all secondary plot soils than in the primary plot soil (Johnson et al., 2001). The distribution pattern of exchangeable $\mathrm{Ca}$ in the study sites showed a similar trend with exchangeable $\mathrm{Mg}$. On the other hand, exchangeable $\mathrm{Na}$ did not show any relationships in term of the fallow periods. This trend was in line with study as reported by Etsuko et al. (2004).

The contents of clay and sand at surface soils $(0-10 \mathrm{~cm}$ depth) showed no significant differences in all study sites, except for Belukar II. The content of sand in the soils of Belukar II was the highest among all study sites, meanwhile the lowest content of sand was also observed at the depth of $0-10 \mathrm{~cm}$ in this site. However, there was a significant relationship between the soil clay and sand contents at the depth of $0-10 \mathrm{~cm}$ in these study sites as illustrated in Fig. 3. The bulk density was higher at the depth of $20-30 \mathrm{~cm}$ than at the depth of 0-10 $\mathrm{cm}$. The lower bulk density usually showed the higher porosity. Generally, the higher bulk density indicated the compaction of soil in the site. Similarly, Ohta and Effendi (1992a) observed that bulk density increased with depth, and was inversely correlated with the clay and carbon contents in each horizon at lowland Dipterocarp forest in East Kalimantan, Indonesia. Soils at 0-10 cm depth was harder than at 20-30 cm depth. At the depth of 0-10 cm, the soil hardness decreased with increasing fallow periods. On the other hand, unclear difference were observed for the soil hardness at different depths in the study sites as shown in Table 1. This indicated that the soil hardness at different depth was not relatively changed at the early stage of secondary succession process till 20 years fallow period. This may probably be due to the variation of soil texture and porosity under the similar parent materials. The soil hardness was significantly high probably because of the dead and carbonized tree roots of the former vegetation (Ogino et al., 2000). 


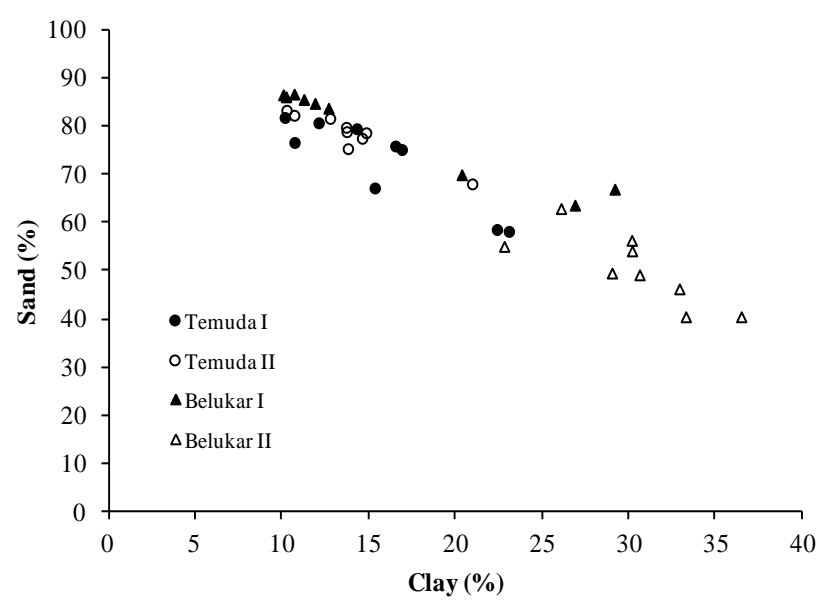

Fig. 3: Relationship between sand and clay contents at the depth of $0-10 \mathrm{~cm}$ in the study sites. Temuda I $\left(y=-1.76 x+100.37, R^{2}=0.80\right)$, Temuda II $\left(y=-1.41 x+98.13, R^{2}=0.90\right)$, Belukar I $\left(y=-1.23 x+98.93, R^{2}=0.95\right)$, and Belukar II $\left(y=-1.47 x+94.85, R^{2}=0.63\right)$.

\section{Conclusion}

This study indicated that soil physiochemical properties differed at different stages of fallow lands $(3,5,10$, and 20 years old secondary forests) as well as at different soil depths (0-10 cm and 20-30 cm depths). Under similar parent material and land use history (slash and burn), several soil physicochemical properties showed significant differences among the different ages of secondary forests after abandonment. This indicated that the soil morphological and physiochemical properties developed and changes at early secondary succession process following fallow period. The development and changes of species composition of plant seedlings and saplings after slash and burn process was mostly influenced by secondary succession process and fallow age in abandoned lands (Karyati et al., 2013). In addition, the fallowing period of 20 years was probably insufficient to allow fallow lands to recover vegetation and soil parameters which could increase the high ability to provide sufficient in both above ground and below ground biomass as well as $\mathrm{C}$ stock in vegetation and soil (Karyati, 2013). The information on forest soil properties is important and critical to understand the change and dynamic process under various stages of secondary forests. The comprehensive understanding about soil properties and development process is useful for addressing future management of secondary forests and the related issues like global climate change, biodiversity, carbon marketing and sustainability of ecosystem service of secondary forests.

\section{Acknowledgements}

We acknowledge to Malaysian Palm Oil Board (MPOB) for supporting the funding of this research project. We thank all support staff at Faculty of Resource Science and Technology, Universiti Malaysia Sarawak, En. Hidir Marzuki, En. Sekudan Tedong, En. Salim Arip and En. Muhd Najib Fardos for their field assistance and companionship during the survey. 


\section{References}

Abebrese, M.O., 2002. Tropical secondary forest management in Africa. In: Workshop on Tropical Secondary Forest Management in Africa: Reality and Perspectives, 9-13 December 2002. Kenya: Nairobi, pp.1-7.

Andriesse , J.P., Schelhaas, R.M., 1987a. A monitoring study on nutrient cycles in soils used for shifting cultivation under various climatic conditions in Tropical ASIA. III. The effects of land clearing through burning on fertility level. Agriculture, Ecosystems \& Environment, 19:311-332.

Andriesse , J.P., Schelhaas, R.M., 1987b. A monitoring study of nutrient cycles in soils used for shifting cultivation under various climatic conditions in Tropical Asia. II. Nutrient stores in biomass and soil results of baseline studies. Agriculture, Ecosystems \& Environment, 19:285-310.

Butt, G., 1983. Semi-detailed site evaluation of Sabal Forest Reserve northern half. Forest Research Report No. S.S.2. Soil Survey Unit, Research Section, Forest Department, Sarawak.

Etsuko, W., Katsutoshi, S., Yukoh, O., Nouanthasing, L., Chanphengxay, A., 2004. Soil fertility and farming systems in a slash and burn cultivation area of Northern Laos. Southeast Asian Studies, 41(4):519-537.

Feldpausch, T.R., Prates-Clark, C.C., Fernandes, E.C.M., Riha, S.J., 2007. Secondary forest growth deviation from chronosequence predictions in Central Amazonia. Global Change Biology, 13:967-979.

Fisher, R.F., Binkley, D., 2000. Ecology and management of forest soils, $3^{\text {rd }}$ John Wiley \& Sons, Inc, USA.

Harris, R. W., 1992. Arboriculture: Integrated management of landscape trees, shrubs and vines. Prentice Hall Career \& Technology, New Jersey.

Hazra, P., Som, M.G., 2006. Vegetable Science. Kalyani Publishers, New Delhi.

Johnson, C.M., Vieira, I.C.G., Zarin, D.J., Frizano, J., Johnson, A.H., 2001. Carbon and nutrient storage in primary and secondary forests in Eastern Amazônia. Forest Ecology \& Management, 147:245-252.

Johnson, E.A., Miyanishi, K., 2007. Disturbance and succession, in: Johnson, E.A., Miyanishi, K. (Eds.), Plant Disturbance Ecology: the Process and the Response, Elsevier, USA, pp.1-14.

Jomo, K.S., Chang, Y.T., Khoo, K.J., 2004. Deforesting Malaysia: The political, social ecology of agricultural expansion and commercial logging. Zed Books Ltd., United Kingdom.

Jordan, C.F., 1985. Nutrient Cycling in Tropical Forest Ecosystem. Wiley, New York.

Juo, A.S.R., Manu, A., 1996. Chemical dynamics in slash-and-burning agriculture. Agriculture, Ecosystems \& Environment, 58:49-60.

Karyati, Ipor, I.B., Jusoh, I., Wasli, M.E., 2012. Suitability of plant species for agroforestry program at Sri Aman, Sarawak. In: Ahmad, F.B., Muid, S., Ipor, I.B., Zainudin, R., Wasli, M.E., Kalu, M., Assim, Z.B. (Eds.), Taxonomy and Ecology: Beyond Classical Approaches. Universiti Malaysia Sarawak, Malaysia, pp.203-213.

Karyati, 2013. Ecology and carbon sequestration of secondary forests at Sabal, Sarawak. PhD Thesis, Universiti Malaysia Sarawak.

Karyati, Ipor, I.B., Jusoh, I., Wasli, M.E., 2013. Composition and diversity of plant seedlings and saplings at early secondary succession of fallow lands in Sabal, Sarawak. Acta Biological Malaysiana, 2(3):85-94. 
Keddy, P.A., 2007. Plants and vegetation: Origins, processes, consequences. Cambridge University Press, New York.

Kendawang, J.J., Ninomiya, I ., Tanaka, K., Ozawa, T., Hattori, D., Tanaka, S., Sakurai, K., 2007. Effects of burning strength in shifting cultivation on the early stage of secondary succession in Sarawak, Malaysia. Tropics, 16:309-321.

Lamb, D., Erskine, P.D., Parrotta, J.A., 2005. Restoration of degraded tropical forest landscapes. Science, 310:1628-1632.

Lanly, J.P., 1982. Tropical forest resources. FAO Forestry Paper 30. FAO, Rome, Italy.

Latiff, A., Zakri, A.H., 1998. Environmental and conservation issues in Malaysia, in Ismail, G., Mohamed, M. (Eds.), Biodiversity conservation in Asia: Emerging issues and regional needs. ASEAN Academic Press, London, pp.138-164.

Lu, D., Mausel, P., Moran, E., 2002. Linking Amazonian secondary succession forest growth to soil properties. Land Degradation \& Development, 13:331-343.

Misra, K.C., 1992. Manual of Plant Ecology. Raju Primlani, New Delhi.

Mittelman, A., 2001. Secondary forests in the Lower Mekong Sub-region: An overview of their extent, roles and importance. Journal of Tropical Forest Science, 13(4):671-690.

Nakano, K., Miyauchi, N., 1996. Changes in physical and chemical properties of surface soil in a swidden and subsequent fallow in a Northwestern Region of Malaita Island, Solomon Islands. South Pacific Study, 17(1):1-20.

NRCS, 2002. Field book for describing and sampling soils, Version 2.0. In: Schoeneberger, P.J., Wysocki, D.A., Benham, E.C., Broderson, W.D. (Eds.), Natural Resources Conservation Service, National Soil Survey Centre, Lincoln, NE.

Nye, P.H., Greenland, D.J., 1960. The soil under shifting cultivation. Commonwealth Bureau of Soils Technical Communication No.51. Commonwealth Agricultural Bureau, Farnham.

Ogino, K., Lee, H.S., Kendawang, J.J., 2000. Proceedings of Workshop on Forest Ecosystem Rehabilitation. Forest Department Sarawak, Sarawak.

Ohta, S., Effendi, S., 1992a. Ultisols of lowland dipterocarp forest in East Kalimantan, Indonesia I. Morphology and physical properties. Soil Science \& Plant Nutrition, 38(2):197-206.

Ohta, S., Effendi, S, 1992b. Ultisols of lowland dipterocarp forest in East Kalimantan, Indonesia II. Status of carbon, nitrogen, and phosphorus. Soil Science and Plant Nutrition, 38(2):207-216.

Ohta, S., Effendi, S., Tanaka, N., Miura, S., 1993. Ultisols of lowland dipterocarp forest in East Kalimantan, Indonesia III. Clay minerals, free oxides, and exchangeable cations. Soil Science \& Plant Nutrition, 39(1):1-12.

Oriola, E.O., Ifabiyi, I.P., Hammed, A.T., 2010. Impact of reforestation in a part of degrading natural ecological system of Ilorin, Kwara State, Nigeria. African Journal of Agricultural Research, 5(20):2811-2816.

Ramakrishnan, P.S., Kushwaha. S.P.S., 2001. Secondary forests of the Himalaya with emphasis on the north-eastern hill region of India. Journal of Tropical Forest Science, 13(4):727-747.

Sanchez, P.A., 1987. Management of acid soils in the humid tropics of Latin America, in Proceedings of an IBSRAM Inaugural Workshop: Management of Acid Tropical Soils for Sustainable Agriculture, Bangkok, pp.63-107.

Schedlbauer, J.L., Kavanagh, K.L., 2008. Soil carbon dynamics in a chronosequence of secondary forests in Northeastern Costa Rica. Forest Ecology \& Management, 255:1326-1335. 
Simmonds, N.W., 1972. The evolution of the bananas. Longman Publication, London.

Soil Survey Staff, 1994. Keys to soil taxonomy. $6^{\text {th }}$ Ed. U.S. Department of Agriculture \& Soil Conservation Service, Washington, DC.

Soil Survey Staff, 2006. Keys to Soil Taxonomy. $10^{\text {th }}$ Ed. U.S. Department of Agriculture \& Natural Resources Conservation Service, Washington, DC.

Tanaka, S., Wasli, M.E., Seman, L, Lee, A., Kendawang, J.J., Sakurai, K., Morooka, Y., 2007a. Ecological study on site selection for shifting cultivation by the Iban of Sarawak, Malaysia. A case study in the Mujong River Area. Tropics, 16(4):357-371.

Tanaka, S., Wasli, M.E., Seman, L, Lee, A., Kendawang, J.J., Sakurai, K., Morooka, Y., 2007b. Soil properties of secondary forests under shifting cultivation by the Iban of Sarawak, Malaysia in relation to vegetation condition. Tropics, 16(4):385-398.

Tanaka, S., Tachibe, S., Wasli, M.E., Lat, J., Seman, L., Kendawang, J.J., Iwasaki, K., Sakurai, K., 2009. Soil characteristics under cash crop farming in upland areas of Sarawak, Malaysia. Agriculture, Ecosystems \& Environment, 129:293-301.

Teng, S.C., 1993. Keys to soil classification in Sarawak. Technical Paper 10. Soils Division, Research Branch, Department of Agriculture, Sarawak.

Uhl, C., 1987. Factors controlling succession following slash-and-burn agriculture in Amazonia. Journal of Ecology, 75:377-407.

Van Do, T., Osawa, A., Thang, N.T., 2010. Recovery process of a mountain forest after shifting cultivation in Northwestern Vietnam. Forest Ecology \& Management, 259:1650-1659.

Wasli, M.E. Tanaka, S., Kendawang, J.J., Seman, L., Unang, B., Lat, J., Abdu, A., Morooka, Y., Sakurai, K., 2009. Vegetation conditions and soil fertility of fallow lands under intensified shifting cultivation systems in Sarawak, Malaysia. Tropics, 18(3):115-126.

Whitmore, T.C., 1975. Tropical rain forests of the Far East. Oxford University Press, United Kingdom. 